\title{
WATER QUALITY ANALYSIS IN A RIVER IN SUB WATERSHED JATIROTO EAST JAVA, INDONESIA
}

\author{
*Noor Salim ${ }^{1}$ \\ ${ }^{1}$ Faculty of Engineering, University of Muhammadiyah Jember, Indonesia
}

*Corresponding Author, Received: 06 Oct. 2021, Revised: 01 Dec. 2021, Accepted: 09 Jan. 2022

\begin{abstract}
One of the factories that produces produce waste is the Jatiroto Sugar Factory, which is located in Lumajang Regency, East Java Province, Indonesia. Besides being affected by industrial waste from the Jatiroto sugar factory, rivers in the sub-watershed area of the Jatiroto river, are also affected by waste from agricultural areas on either side of the river. From this, further research is needed regarding the analysis of water quality in rivers in the Jatiroto sub-watershed area. This study evaluated the water quality of the Jatiroto Sugar Factory Outlet and the Jatiroto River using chemical parameters which include Biological Oxygen Demand (BOD), Chemical Oxygen Demand (COD), Dissolved Oxygen (DO), and pH. Based on Government Regulation No. 82 the Year 2001 class II and class III and Minister of Environment Decree No. 115 of 2003, this chemical parameter exceeds the threshold of the quality standard in the classification of water quality standard classes. This is caused by the decomposition, decomposition, or dilution of organic materials or rainwater, the presence of additional oxygen from the photosynthetic process of aquatic plants. From this research, it can be concluded that the water quality of the Jatiroto River in terms of chemical parameters $(\mathrm{pH}$, BOD, COD, and DO) has decreased or has been polluted, due to waste from the Jatiroto Sugar Factory.
\end{abstract}

Keywords: Laboratory test; Waste; Water quality

\section{INTRODUCTION}

In Indonesia, environmental pollution is the most prominent issue today, along with the increasing number of factories that aim to meet the needs of the growing population. Industrial waste in the form of gas, liquid, solid often endangers the health and safety of the surrounding community. These factories produce a large amount of waste, and if they are not managed properly and responsibly, they will have a negative effect on the environment [1]. to minimize the negative impact of factory activities on the environment, it is necessary to analyze the water quality [2]. According to environmental law No.4 of 1982, pollution is the entry or inclusion of living things, substances, energy, or and/or other components into the environment, or and/or changes in the environmental order by human activities or natural processes, so that the quality of the environment decreases to the point of certain level which causes the environment to become less or unable to function according to its designation [3]. The waste produced by the factory contains various elements that are harmful to human life, one of which is heavy metals [4]. Heavy metals are naturally present in the soil and cannot be degraded, can remain in the soil and water bodies for a long time, so they will continue to increase over time [5]. One of the factories that produces produce waste is the Jatiroto Sugar Factory, which is located in Lumajang Regency, East Java Province, Indonesia.
The development of the Jatiroto Sugar Factory under PTPN XI from 1996 to 2019 has had a major impact on the social, economic, and cultural life of the community and employees of the Jatiroto Sugar Factory in Kaliboto Lor Village, Jatiroto District. One of the impacts is increasing job opportunities and becoming the livelihood of the community, especially those who living living livelife in the factory location. However, on the other hand, there has been environmental pollution in Sidorejo Village, Rowokangkung District, due to the disposal of liquid waste from the Jatiroto Sugar Factory into the river in the Sidorejo Village. The river is part of the Jatiroto sub-watershed. The river has various functions, ranging from irrigating food crops, fishing, or daily necessities. If the water conditions are getting more and more polluted, the surrounding community will be reluctant to utilize it. Furthermore, water can be a source of dangerous diseases can cause itching, diarrhea, and so on. If industrial waste enters the rice fields, rice plants will be contaminated with various waste components, such as heavy metals. It is not uncommon for crops to contain industrial waste residues. According to Kurnia [6], Sujaul et al [7], and Arif et al [8], agricultural environmental pollution that occurs in several places is caused by industry. The development must be environmentally sound, that is, from the start of the development it is planned until the construction operation starts [9]. 
Besides being affected by industrial waste from the Jatiroto sugar factory, rivers in the Jatiroto subwatershed area are also affected by waste from agricultural areas on either side of the river. Heavy metals found in the agricultural environment have a negative effect because they are toxic in all aspects of living things [10]. Some heavy metal ions, such as arsenic (As), lead $(\mathrm{Pb})$, cadmium $(\mathrm{Cd})$, and mercury $(\mathrm{Hg})$ are harmful to human health and survival. Even at low concentrations, heavy metal ions can have a direct effect on human health because they accumulate in the food chain. Like other sources of environmental pollution, heavy metals can be transferred to areas that are very far away in the environment, then they have the potential to disrupt the life of environmental biota and ultimately affect human health even though for a long time and far from the main pollution source [11].

With the impact of the river in the Jatiroto subwatershed area from the impact of existing waste, both waste from the Jatiroto sugar factory industry and agricultural areas. So further research is needed to about water quality analysis in rivers in the Jatiroto sub-watershed area.

\section{RESEARCH SIGNIFICANCE}

Water quality is an essential component of human living. Poor waters quality can be a source of dangerous diseases, can cause itching, diarrhea, and so on so that it can endanger human health. Near the Jatiroto River, there is Jatiroto Sugar Factory which produces waste. This waste has the potential to pollute the rivers around the factory. Therefore, it is necessary to analyze the water quality in the Jatiroto river which can provide information about water quality and pollution quality standard threshold.

\section{METHODOLOGY}

\subsection{Research Location}

This research is located on the Jatiroto river which is in the Jatiroto sub-watershed, namely upstream of the river in Nyeoran Village, Jatiroto District, and downstream of the Jatiroto River in Sidorejo Village, Rowokangkung District, in the administrative area of Lumajang Regency, East Java, Indonesia

\subsection{Data Collection}

In the implementation of water quality monitoring, the terms how to collect and manage water samples include the following.

\subsubsection{Preparation for Sampling of Water}

Before taking water samples, preparations must be done as well as possible so that during the field time things do not occur that can hinder and complicate the water sampling process. These preparations include:
a. Preparation of field maps
b. Preparation of sampling equipment
c. Preparation of sample bottles
d. Preparation of reagents and necessary chemicals.
e. Preparation of measuring equipment

\subsubsection{Sampling Points}

According to the Indonesian National Standard (SNI) [12], river water sampling points are determined based on river water discharge which is regulated with the following conditions:

a. For rivers with a discharge of less than $5 \mathrm{~m}^{3} /$ second, samples are taken at a point in the middle of the river at a depth of $0.5 \mathrm{x}$ depth from the surface or taken using an integrated sampler to obtain an even sample of water from the surface to bottom.

b. Rivers with a discharge between 5-150 $\mathrm{m}^{3}$ / second, samples taken at two points respectively at a distance of $1 / 3$ and $2 / 3$ of the river width at a depth of $0.5 \mathrm{x}$ depth from the surface or taken using an integrated sampler to obtain samples water from the surface to the bottom evenly.

c. Rivers with a discharge of more than $150 \mathrm{~m}^{3}$ / sec, minimum samples are taken at six points respectively at a distance of, $1 / 2$, and $3 / 4$ of the river width at a depth of 0.2 and $0.8 \mathrm{x}$ depth from the surface or taken with a disintegratedintegrated collector sampler.

\subsubsection{How to Take Water Samples}

Taking water samples is then removed from the collection tool and collected in a container and combined with samples from other points with the same volume ratio. This sample is then put into a sample bottle and labeled with information on the sampling location.

\subsubsection{Water Sample Management}

\section{a. Filtering}

Filtering was carried out using filter paper with a porous $0.45 \mu \mathrm{m}$. The filter results are put into bottles that have been prepared and labeled with the location, date, and preservative used. Furthermore, the filtered sample is examined in the laboratory to obtain the levels of its parameters.

b. Extraction

Sample extraction is carried out to transfer certain substances into another medium (usually 
organic liquids such as hexane, petroleum ether, etc.). Extraction is carried out to determine certain parameters such as pesticides or fats fats oils/fats.

c. Preserved

Preservation of samples is carried out to inhibit changes in the chemical composition of the water samples taken.

Table 1 Parameters preserved and how to preserve them

\begin{tabular}{|c|c|c|c|}
\hline Parameter & $\begin{array}{l}\text { Storage } \\
\text { Bottles }\end{array}$ & $\begin{array}{c}\text { Preservation } \\
\text { method }\end{array}$ & $\begin{array}{c}\text { Storage } \\
\text { limit }\end{array}$ \\
\hline BOD & $\begin{array}{c}\text { Plastic, } \\
\text { glass }\end{array}$ & Cooler & 48 hour \\
\hline COD & $\begin{array}{l}\text { Plastic, } \\
\text { glass }\end{array}$ & $\begin{array}{l}\text { Add sulfuric } \\
\text { acid to } \mathrm{pH}<2\end{array}$ & 48 hour \\
\hline $\mathrm{pH}$ & $\begin{array}{c}\text { Plastic, } \\
\text { glass }\end{array}$ & $\begin{array}{c}\text { Add sulfuric } \\
\text { acid to } \mathrm{pH}<2 \\
\text { and cool down }\end{array}$ & 48 hour \\
\hline DO & $\begin{array}{l}\text { Plastic, } \\
\text { glass }\end{array}$ & Cooled & 48 hour \\
\hline
\end{tabular}

\subsubsection{Field measurement}

Field measurements and analysis are carried out on parameters that are volatile and allow for field inspection. Parameters that are frequently checked in the field include:

a. Temperature

The temperature measurement of the water sample is carried out using an ordinary thermometer or an electronic thermometer. Thermometer readings are made without taking the thermometer/electrode from the water.

b. $\mathrm{pH}$

The $\mathrm{pH}$ parameter or degree of acidity is measured using a meter meter that has been calibrated.

c. Dissolved oxygen

Dissolved oxygen in water is determined using a calibrated DO meter.

\subsubsection{Checked Parameters}

In this study, we will only use several parameters that are considered important by researchers as key parameters that can represent and describe the water quality of the Jatiroto Sugar Factory Outlet and Jatiroto River, namely: Biological Oxygen Demand (BOD), Chemical Oxygen Demand (COD), Dissolved Oxygen (DO) ), $\mathrm{pH}$. The research parameters must fulfill the criteria for Environmental Quality Standards with with Indonesian Government Regulation No. 82 of 2001 concerning water treatment, water quality and control of sugar industry pollution [13].

\subsubsection{Data of Management}

The data management process is carried out by following the steps as follows:

a. Editing data, checking all secondary data that has been collected carefully to ensure that the data is complete and clear according to the parameters to be analyzed.

b. Entering data and processing, after going through the previous process then the data is entered into the computer for analysis.

\section{RESULTS AND DISCUSSIONS}

\subsection{Analysis of Wastewater Quality Parameters for Jatiroto Sugar Factory IPAL}

\subsubsection{BOD Parameter}

Data from the water quality analysis of the Jatiroto IPAL was carried out at 1 point of the collection location using 4 parameters, namely $\mathrm{pH}$, BOD, COD, and DO. The analysis of the BOD value at the wastewater treatment plant is carried out by analyzing the wastewater quality data, the average BOD value can be seen in Table 2 and Figure 1.

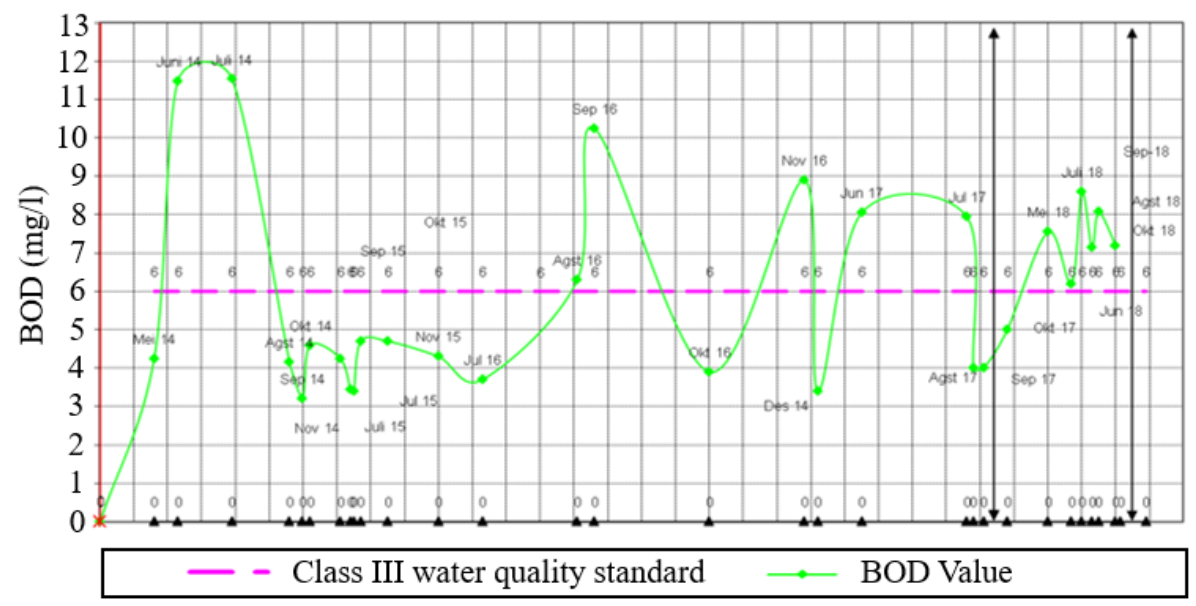


Fig 1. IPAL BOD Value

Table 2 Results of analysis of BOD Parameter IPAL in mg/L

\begin{tabular}{|c|c|c|c|c|c|c|c|c|c|c|c|c|}
\hline \multirow{2}{*}{ Year } & \multicolumn{12}{|c|}{ Month } \\
\hline & Jan & Feb & Mar & Apr & May & Jun & Jul & Aug & Sep & Oct & Nov & Dec \\
\hline 2014 & & & & & 7.686 & 40.16 & 31.52 & 7.13 & 3.96 & 7.47 & 8.3 & \\
\hline 2015 & & & & & & & 5.9 & 7.5 & 10.1 & 11.7 & 13.32 & \\
\hline 2016 & & & & & & & 9.14 & 26.86 & 39.98 & 8.87 & 34.8 & 15.1 \\
\hline 2017 & & & & & & 17.4 & 19.53 & 18 & 22 & 23 & & \\
\hline 2018 & & & & & 18.64 & 12.24 & 14.52 & 14.40 & 17.98 & 32.46 & & \\
\hline
\end{tabular}

Wastewater quality data at outlet time, wastewater samples were used as BOD analysis materials and compared with Environmental Quality Standards for Sugar Industry wastewater. It can be seen from the table above that the average value of BOD Outlet from 2014 to 2018 is $7.46 \mathrm{mg} / \mathrm{lt}$ and the Environmental Quality Standard value is set at 6 $\mathrm{mg} / \mathrm{lt}$. It indicated that the treatment of water water water wastewater that is discharged from the IPAL outlet of Jatiroto Sugar Factory to Jatiroto River does not comply with the criteria in the existing Government Regulation. According to the
Government Regulation, the BOD outlet is relatively unsafe because the maximum BOD level is $6.0 \mathrm{mg} / \mathrm{l}$.

\subsubsection{COD Parameter (Chemical Oxygen Demand)}

COD (mg / lt) is the amount of oxidizer needed to oxidize organic substances in water. So the higher the COD value, the less oxygen dissolved DO in the water will result in the lower quality of wastewater. Wastewater quality data on COD which includes the average COD outlet can be seen in Table 3 and Figure 2.

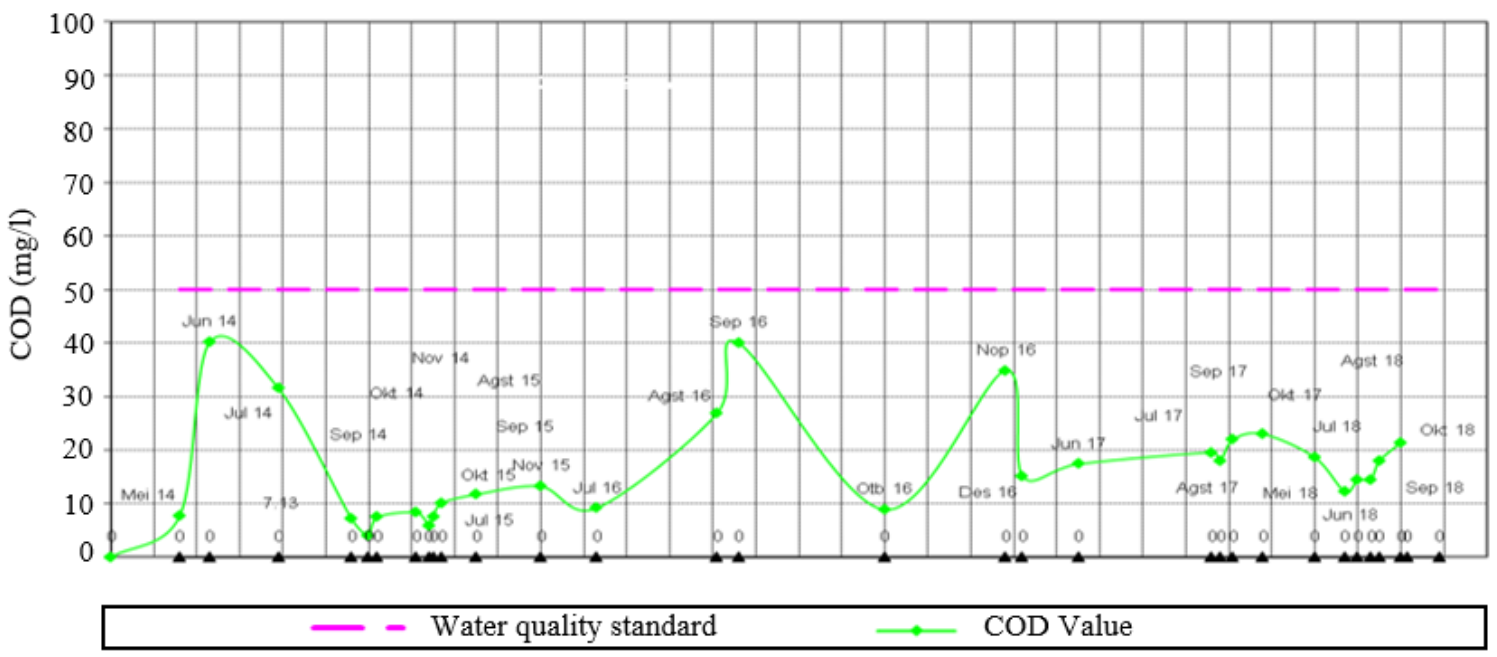

Fig 2. IPAL COD Value

Table 3 Analysis results of COD parameter IPAL in mg/L

\begin{tabular}{|c|c|c|c|c|c|c|c|c|c|c|c|c|}
\hline \multirow{2}{*}{ Year } & \multicolumn{12}{|c|}{ Month } \\
\hline & Jan & Feb & Mar & Apr & May & Jun & Jul & Aug & Sep & Oct & Nov & Dec \\
\hline 2014 & & & & & 7.686 & 40.16 & 31.526 & 7.13 & 3.96 & 7.47 & 8.309 & \\
\hline 2015 & & & & & & & 5.885 & 7.523 & 10.1 & 11.7 & 13.22 & \\
\hline 2016 & & & & & & & 9.14 & 26.86 & 39.98 & 8.87 & 34.84 & 15.11 \\
\hline 2017 & & & & & & 17.39 & 19.53 & 18 & 22 & 23 & & \\
\hline 2018 & & & & & 18.64 & 12.24 & 14.53 & 14.4 & 17.98 & 21.36 & & \\
\hline
\end{tabular}

It can be seen from the table above that the average COD Outlet from 2014 to 2018 is $16.85 \mathrm{mg}$ / lt and the Environmental Quality Standard value is set at $100 \mathrm{mg} / \mathrm{lt}$ It indicated that the treatment of wastewater removed from the IPAL outlet of Jatiroto Sugar Factory to Jatiroto river has to complied the criteria in the existing Government Regulation. According to the Government
Regulation, the COD outlet is relatively safe because the maximum COD level is $100 \mathrm{mg} / \mathrm{l}$.

\subsection{3 pH Parameter}

The $\mathrm{pH}$ parameter shows the hydrogen ion concentration in water. Water that is still fresh from the mountains has a high $\mathrm{pH}$, then becomes acidic due to the addition of organic materials which then 
releases $\mathrm{CO}_{2}$ if it breaks down because the hydrogen ion content greatly affects the $\mathrm{CO}_{2}$ content. water water wastewater quality data on the $\mathrm{pH}$ outlet parameters can be seen in Table 4 and Figure 3.

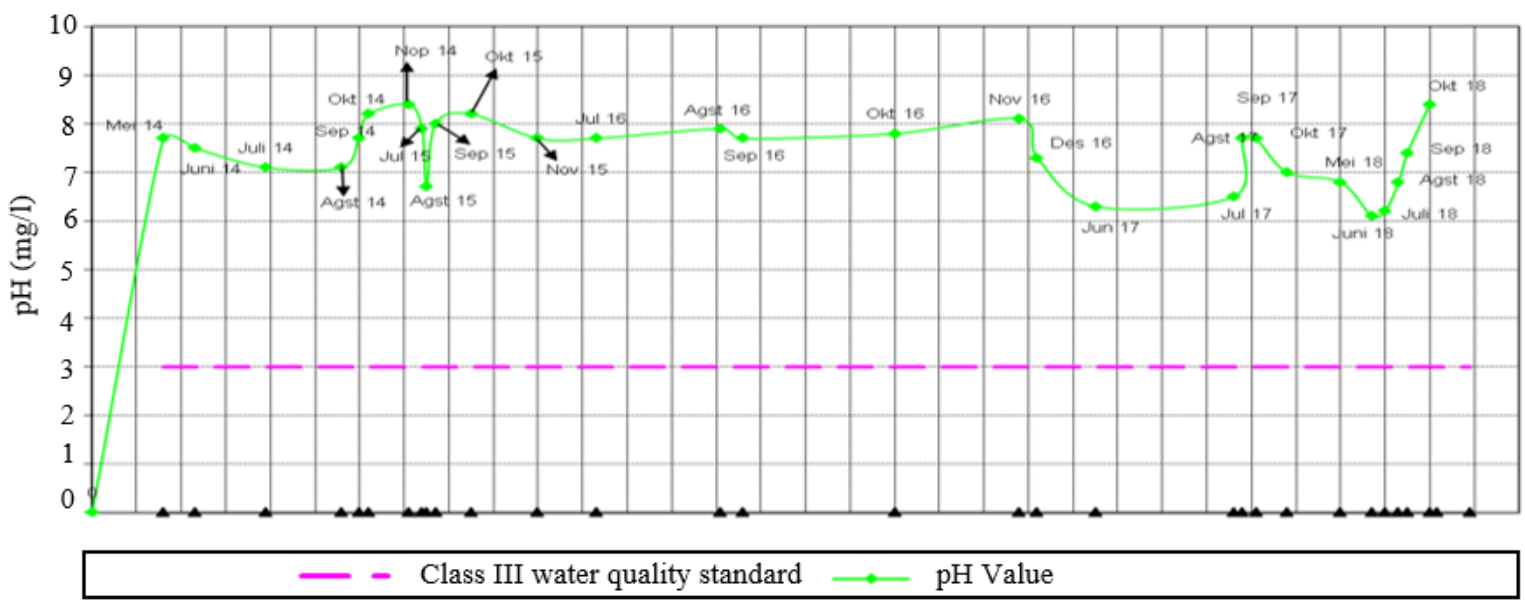

Fig 3. IPAL pH value

Table 4 IPAL Analysis Results Parameters pH

\begin{tabular}{|c|c|c|c|c|c|c|c|c|c|c|c|c|}
\hline \multirow{2}{*}{ Year } & \multicolumn{12}{|c|}{ Month } \\
\hline & Jan & Feb & Mar & Apr & May & Jun & Jul & Aug & Sep & Oct & Nov & Dec \\
\hline 2014 & & & & & 7.7 & 7.5 & 7.10 & 7.1 & 7.7 & 8.2 & 8.4 & \\
\hline 2015 & & & & & & & 7.7 & 6.7 & 8 & 8.2 & 7.7 & \\
\hline 2016 & & & & & & & 7.7 & 7.9 & 7.7 & 7.8 & 8.1 & 7.3 \\
\hline 2017 & & & & & & 6.3 & 6.5 & 7.7 & 7.7 & 7 & & \\
\hline 2018 & & & & & 6.8 & 6.1 & 6.2 & 6.8 & 7.4 & 8.4 & & \\
\hline
\end{tabular}

It can be seen from the table above that the average pH Outlet value from 2014 to 2018 is 7.53 mg / lt and the Environmental Quality Standard value is set $6-9$. It indicated that the treatment of wastewater that is discharged from the IPAL outlet of Jatiroto Sugar Factory to Jatiroto River has met the criteria in the existing Government Regulation. According to the Government Regulation, a pH outlet is relatively safe because the maximum $\mathrm{pH}$ level is $6-9$.

\subsection{Analysis of Water Quality Parameters in Jatiroto River}

\subsubsection{BOD (Biological Oxygen Demand) Parameter}

The water quality condition of the Jaritoto River from the upstream is designated for Class III River Water Body and Class II River Water still does not comply with the river water quality standards, with a moderately polluted status, while the waste that needs to be considered in the Jatiroto River in the downstream is sewage Jatiroto Sugar Factory, which entered Jatiroto river through the Banter flavor. for moderate polluted downstream areas where the water condition is very polluting for the community, especially when the factory is producing, for the parameters that have decreased are BOD, Nirit for the upstream area being done,
BOD, COD, Oil/fat and Nitrite in the downstream area.

The current water condition is with with the allotment of the Government Regulation. No. 82 of 2001 with class II water quality standards. Jatiroto river apart from receiving waste from the Jatiroto Sugar Factory is also from domestic and agricultural waste as well as leather factories, and others. Therefore, every month, keep monitoring the condition of the water quality, so it is hoped that there will be an increase in the quality standards of the river water. Jatiroto River water quality data on BOD parameters can be seen in Table 5 . and Figure 4 below.

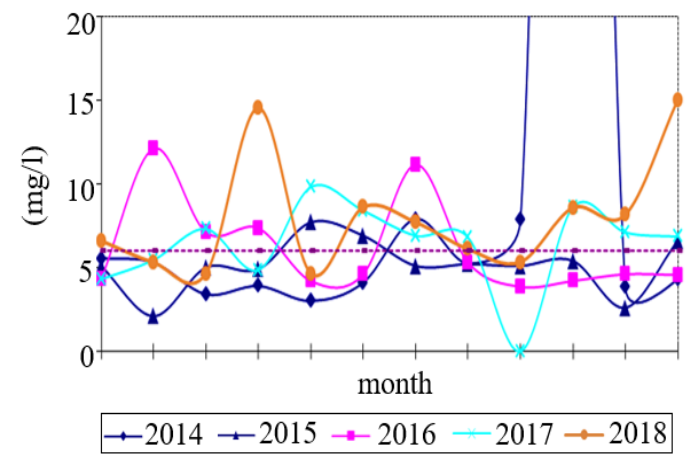

Fig 4. Jatiroto River BOD Value 
Table 5 Results of analysis of BOD parameter IPAL in mg/L

\begin{tabular}{|c|c|c|c|c|c|c|c|c|c|c|c|c|}
\hline \multirow{2}{*}{ Year } & \multicolumn{12}{|c|}{ Month } \\
\hline & Jan & Feb & Mar & Apr & May & Jun & Jul & Aug & Sep & Oct & Nov & Dec \\
\hline 2014 & 5.55 & 5.3 & 3.4 & 3.9 & 3 & 4.1 & 7.9 & 5.25 & 7.85 & 101.9 & 3.885 & 4.3 \\
\hline 2015 & 5.1 & 2.1 & 5 & 4.9 & 7.7 & 6.9 & 5.1 & 5.2 & 5.1 & 5.4 & 2.6 & 6.6 \\
\hline 2016 & 4.3 & 12.1 & 7.1 & 7.35 & 4.2 & 4. & 11.15 & 5.3 & 3.85 & 4.2 & 4.6 & 4.55 \\
\hline 2017 & 4.3 & 5.45 & 7.3 & 4.85 & 9.8 & 8.4 & 6.9 & 6.8 & 8.5 & 8.6 & 7.1 & 6.85 \\
\hline 2018 & 6.6 & 5.3 & 4.65 & 14.53 & 4.65 & 8.6 & 7.7 & 6.1 & 5.33 & 8.57 & 8.51 & 15.01 \\
\hline
\end{tabular}

It can be seen from figure 4 and table 5 that the maximum value of BOD Jatiroto river in 2014 was $101.9 \mathrm{mg} / \mathrm{L}$ and the average value of BOD Jatiroto river from from 2014 to 2018 was $8.19 \mathrm{mg} / \mathrm{L}$. The Class II Environmental Quality Standard was set at $6 \mathrm{mg} / \mathrm{L}$. It indicated that the water treatment of the water bodies sampled in the Jatiroto River did not comply with the criteria in the existing Government Regulation. According to the Government Regulation, BOD is relatively unsafe because the maximum BOD level of BML II is $6 \mathrm{mg} / \mathrm{L}$.

\subsubsection{DO ( dissolved oxygen ) Parameter}

Dissolved oxygen value means that an of gaseous oxygen $\left(\mathrm{O}_{2}\right)$ is dissolved in an aqueous solution [14]. This value is measured in $\mathrm{mg} / \mathrm{l}$ or ppm units. This dissolved oxygen is used as a sign of the degree of contamination of the existing waste. The greater the dissolved oxygen, the relatively small the degree of impurity. The water quality data of the Jatiroto River on DO parameters can be seen in Table 6 and Figure 5.

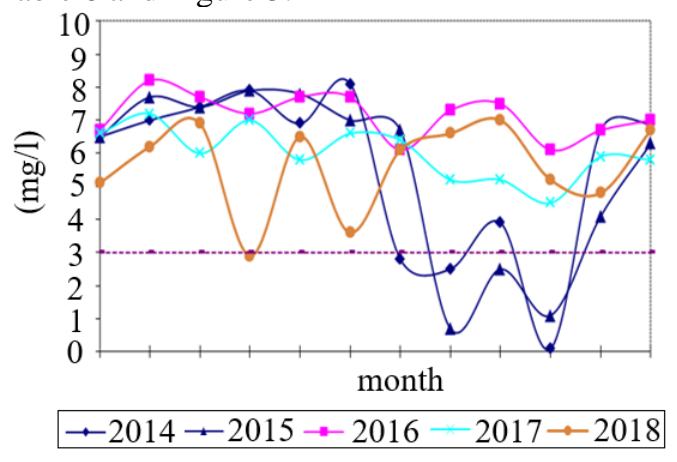

Fig 5. Graph Comparison of the Concentration of "DO" Jatiroto River 2014 - 2018

Table 6 Analysis Results of DO Parameter IPAL in mg/L

\begin{tabular}{|c|c|c|c|c|c|c|c|c|c|c|c|c|}
\hline \multirow{2}{*}{ Year } & \multicolumn{12}{|c|}{ Month } \\
\hline & Jan & Feb & Mar & $\mathrm{Apr}$ & May & Jun & Jul & Aug & Sep & Oct & Nov & Dec \\
\hline 2014 & 6.5 & 7 & 7.4 & 7.9 & 6.9 & 8.1 & 2.8 & 2.5 & 3.9 & 0.1 & 6.7 & 6.9 \\
\hline 2015 & 6.5 & 7.7 & 7.4 & 7.9 & 7.8 & 7 & 6.7 & 0.7 & 2.5 & 1.1 & 4.1 & 6.3 \\
\hline 2016 & 6.7 & 8.2 & 7.7 & 7.2 & 7.7 & 6.6 & 6.1 & 7.3 & 7.5 & 6.1 & 6.7 & 7 \\
\hline 2017 & 6.6 & 7.2 & 6 & 7 & 5.8 & 6.6 & 6.4 & 5.2 & 5.2 & 4.5 & 5.9 & 5.8 \\
\hline 2018 & 5.1 & 6.2 & 6.9 & 2.9 & 6.5 & 3.6 & 6.1 & 6.6 & 7 & 5.2 & 4.8 & 6.7 \\
\hline
\end{tabular}

It can be seen from figure 5 and table 6 that the maximum value of the DO Jatiroto river in 2014 was $8.1 \mathrm{Mg} / \mathrm{L}$ and the average value of the $\mathrm{DO}$ Jatiroto river from from2014 to 2018 was $8.19 \mathrm{mg} /$ L. The Class II Environmental Quality Standard was set at $3 \mathrm{mg} / \mathrm{L}$. It indicated that the water treatment of the Water Body that was sampled in the Jatiroto river did not comply with the criteria in the existing Government Regulation. According to the Government Regulation, DO is relatively unsafe because the maximum DO level of BML II is $3 \mathrm{mg}$ / lt.

\subsubsection{COD (Chemical Oxygen Demand) Parameter}

From the laboratory test results, the COD value of water samples in Jatiroto River from upstream is designated for Class III River Water Body and Class II River Water still does not comply with the river water quality standards, with moderate polluting status, while the waste that needs attention is in the river. Jatiroto in the downstream area is waste disposal from the Jatiroto Sugar Factory, which enters Jatiroto River via the Banter favour favor. for moderate polluted downstream areas where the water conditions are very polluting for the community, especially when the factory is doing production. The water quality data of the Jatiroto River on COD parameters can be seen in Table 7 and Figure 6. 


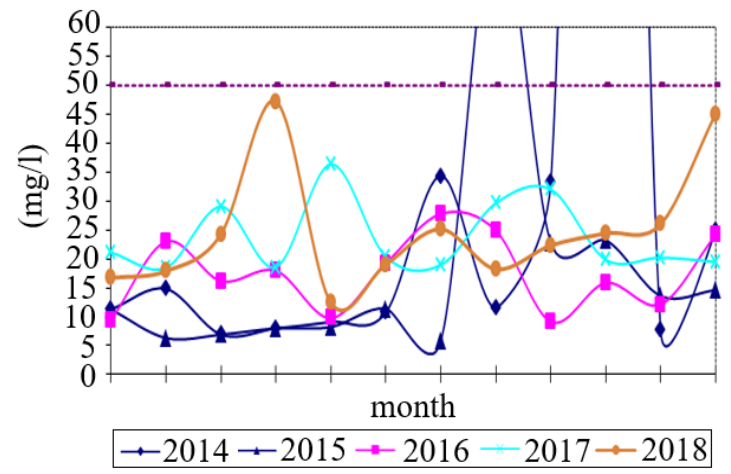

Fig 6. Comparison Graph of “COD” Concentration in Jatiroto River 2014 - 2018

Table 7 Analysis Results of COD Parameter IPAL in mg/L

\begin{tabular}{|c|c|c|c|c|c|c|c|c|c|c|c|c|}
\hline \multirow{2}{*}{ Year } & \multicolumn{12}{|c|}{ Month } \\
\hline & Jan & Feb & Mar & Apr & May & Jun & Jul & Aug & Sep & Oct & Nov & Dec \\
\hline 2014 & 11.27 & 14.83 & 6.91 & 7.982 & 9.089 & 10.74 & 34.36 & 11.52 & 33.23 & 311.1 & 7.651 & 24.85 \\
\hline 2015 & 11.27 & 6.32 & 6.91 & 7.982 & 8.223 & 11.43 & 5.798 & 80.41 & 22.8 & 23.24 & 13.59 & 14.62 \\
\hline 2016 & 9.4 & 23.02 & 16.17 & 17.96 & 9.781 & 19.26 & 27.81 & 24.92 & 9.127 & 15.85 & 12.15 & 24.19 \\
\hline 2017 & 21.12 & 18.47 & 29.04 & 18.59 & 36.39 & 20.36 & 18.98 & 29.63 & 32.05 & 19.87 & 20.25 & 19.49 \\
\hline 2018 & 16.72 & 17.89 & 24.28 & 47.25 & 12.4 & 19.04 & 25.14 & 18.23 & 22.34 & 24.43 & 26.02 & 45.12 \\
\hline $\begin{array}{l}\text { It } \\
\text { sim }\end{array}$ & & & & & & & $\begin{array}{l}\text { Nogos } \\
\text { Kedun }\end{array}$ & & $\begin{array}{c}3.8 \\
9.14\end{array}$ & 70 & & 240 \\
\hline
\end{tabular}
and 2015 was $311.1 \mathrm{Mg} / \mathrm{L}$ and $80.4 \mathrm{Mg} / \mathrm{L}$ respectively. The average value of the COD Jatiroto river from 2014 to 2018 was $8.19 \mathrm{mg} / \mathrm{L}$ and the Class II Environmental Quality Standard was set at $50 \mathrm{mg} / \mathrm{L}$. It indicated that the Water Body Water treatment was sampled Jatiroto River has not to compliedcomplied the criteria in the existing Government Regulation. According to the Government Regulation, COD is relatively unsafe because the maximum COD level for BML II is 25 $\mathrm{mg} / \mathrm{L}$ and the maximum COD level for BML III is $50 \mathrm{mg} / \mathrm{L}$.

\subsection{Villages Affected by River Pollution}

The development of the Jatiroto Sugar Factory has had an impact on changes due to the impact of river pollution which is caused by the disposal of waste from the Jatiroto Sugar Factory from the results of liquid and solid waste processing. Not all of the effects of the Jatiroto Sugar Factory are explained, but only some aspects of life that are explained are expected to know the changes, in line with the growth of the Jatiroto Sugar Factory, it has a direct or indirect impact on the lives of the people of Sidorejo Village and Rowokangkung Village, Rowokangkung District.

Table 8 Total Population

\begin{tabular}{lccc}
\hline \multicolumn{1}{c}{ Village } & $\begin{array}{c}\text { Area } \\
\mathrm{Km}^{2}\end{array}$ & $\begin{array}{c}\text { Total } \\
\text { population } \\
\left(\mathrm{Km}^{2}\right)\end{array}$ & $\begin{array}{c}\text { Number of } \\
\text { households }\end{array}$ \\
\hline 1. Sidorejo & 8.03 & 5494 & 1896 \\
2. Rowokangkung & 10.63 & 9497 & 3217 \\
$\begin{array}{l}\text { 3. Dawuhan } \\
\text { wetan }\end{array}$ & 28.26 & 8150 & 2800 \\
4. Sumberanyar & 5.72 & 4055 & 1200 \\
\hline
\end{tabular}

From the table above, 2 villages are affected by waste pollution from processing the Jatiroto Sugar Factory in Rowokangkung District, namely Sidorejo Village and Rowokangkung Village. Seen from the table above for the Village of Sidorejo Village Area is $8.03 \mathrm{Km}^{2}$ with a population of 5,494 and 1,896 households, while for Village Rowokangkung can be seen from table 4.5 for the land area of Rowokangkung Village $10.63 \mathrm{Km}^{2}$ with a population of 9,497 and 3,217 households those affected by river pollution resulting from processing at the Jatiroto Sugar Factory.

The people of Sidorejo Village and Rowokangkung Village are very thick with the agricultural area and most of the residents in the two villages are very thick with the character of a farmer. The people of Sidorejo Village and Rowokangkung Village have a very high level of care and cooperation and are very harmonious in dealing with various matters regarding community life in everyday life. The people in Sidorejo and Rowokangkung Villages have the majority of livelihoods as farmers, both who own rice fields and those who do not. The residents of Sidorejo Village depend on agriculture to fulfill their daily needs [15]. So the determinant of the economy of the people of Sidorejo Village is determined by agriculture, namely the agricultural products obtained for each harvest from the land owned by every resident of Sidorejo Village.

\subsection{Environmental Impact}

The disposal process from industrial waste from the Jatiroto Sugar Factory is one of the 
problems for Sidorejo Village, Rowokangkung Village, Rowokangkung District, which is affected by waste from the Jatiroto Sugar Factory in the form of liquid waste from factory processing which has an impact on river pollution in Sidorejo Village and Rowokangkung Village, which was originally The river looks clear and now turns cloudy, smelly, and black black black black brownish-black which causes an unpleasant odor. Based on Government Regulation No. 82 the Year 2001 class II and class III and Minister of Environment Decree No. 115 of 2003 [16], the chemical parameters ( $\mathrm{pH}, \mathrm{BOD}$, COD, and DO) exceed the threshold of the quality standard in the classification of water quality standards.

\section{CONCLUSIONS}

From the results of the analysis and discussion of this research, it can be concluded that the following matters. :

a. Based on Government Regulation No. 82 the Year 2001 class II and class III and Minister of Environment Decree No. 115 of 2003, the chemical parameters ( $\mathrm{pH}, \mathrm{BOD}, \mathrm{COD}$, and DO) exceed the threshold of the quality standard in the classification of water quality standards

b. The decline in chemical parameters is due to the decomposition process, decomposition or dilution of organic materials or rainwater, the presence of additional oxygen from the photosynthetic process of aquatic plants.

c. Based on the results of laboratory analysis, the water quality of the Jatiroto River in terms of chemical parameters ( $\mathrm{pH}, \mathrm{BOD}, \mathrm{COD}$, and DO) has decreased or has been polluted, due to waste from the Jatiroto Sugar Factory during the milling season.

\section{ACKNOWLEDGMENTS}

The author would like to thank Mrs. Rusdiana (lecturer at the Faculty of Engineering, University of Muhammadiyah Jember) and Dwi Erick (former undergraduate student at the Faculty of Engineering, University of Muhammadiyah Jember), for their assistance in conducting this research. This study is supported by the Institute for Research and Community Service, University of Muhammadiyah Jember.

\section{REFERENCE}

[1] Zhang P., Sun H., Yu L., \& Sun T., Adsorption and catalytic hydrolysis of carbaryl and atrazine on pig manure- derived biochars: impact of structural properties of biochars. J Hazard Mater, Vol. 244-245, 2013, pp. 217-224.
[2] Ioele G., Luca M.D., Grande F., Durantane G., Trozzo R., Crupi C., \& Ragno G., Assessment of Surface Water Quality Using Multivariate Analysis: Case Study of the Crati River, Italy. Water, Vol.12, 2020, pp.1-12.

[3] Undang-Undang Repulik Indonesia Nomor 4, Tahun 1982 Tentang Ketentuan-Ketentuan Pokok Pengelolaan Lingkungan Hidup.1982, pp.1-7.

[4] Hashemi S.A., Shokri A.K., \& Tahvildari M., Detecting of heavy metal pollution in steel factory environment health of the North of Iran. Acta Ecologica Sinica, Vol.36, 2016, pp.225-228.

[5] Govindasamy, C., Arulpriya, M., Ruban, P., Francisca, L.J., \& Ilayaraja, A., Concentration of heavy metals in seagrasses tissue the Palk Strait, Bay of Bengal. Int. J. Environ. Sci. 2, 2011, pp.145-153.

[6] Kurnia U., Strategi Pengelolaan Lingkungan Pertanian. Jurnal Sumber Daya Lahan, Vol.2, Issue 1, 2008, pp.59-74.

[7] Sujaul I.M., Hossain M.A., Nasly M.A., \& Sobahan M.A., Effect Of Industrial Pollution On The Spatial Variation Of Surface Water Quality. American Journal of Environmental Science, Vol. 9, Issue 2, 2013, pp.120-129.

[8] Arif A., Malik M.F., Liaqat S., Aslam A, Mumtaz K., Afzal A., Ch D.M., Nisa K., Khurshid F., Arif F., Khalid M.S.Z., \& Javed R., Review Article: Water pollution and industries. Pure Appl. Biol., Vol. 9, Issue 4, 2020, pp.2214-2224.

[9] Zeak W.A.H., Tanggung Jawab Pemerintah Daerah Kabupaten/Kota Dalam Pemberian Izin Lingkungan Menurut UU No. 32 Tahun 2009. Lex Et Societatis, Vol. V, Issue 9, 2017, pp.5-13.

[10] Briffa J., Sinarga E., \& Blundell R., Review Article: Heavy metal pollution in the environment and their toxicological effects on humans. Heliyon. Vol. 6, Issue 9, 2020, pp.1-26.

[11] Suhendrayatna. Bioremoval Logam Berat dengan Menggunakan Mikroorganisme: Suatu Kajian Kepustakaan. Seminar On-Air Bioteknologi untuk Indonesia Abad 21, 2001, pp.1-9.

[12] National Standardization Agency. 2008. Indonesian National Standard (SNI) of Water and wastewater - Section 59: Wastewater sampling method, pp. 1-19, Jakarta.

[13] Government of the Republic of Indonesia. 2001. RI Government Regulation No. 82 of 2001 about 
Water Quality Management and Water Pollution Control, pp.1-41, Jakarta.

[14] Febiyanto, Effects of Temperature and Aeration on The Dissolved Oxygen (DO) Values in Freshwater Using Simple Water Bath Reactor: A Brief Report. Walisongo Journal of Chemistry, Vol.3, Issue 1, 2020, pp.25-30.

[15] Widiantoro B. The Effect of Jatiroto Sugar Factory on the Lives of the Kaliboto Lor Community, Jatiroto District 1996 - 2010, 2013, pp.69-70, Jember: University of Jember.

[16] State Minister Of Environment. Decree of the Minister of State for the Environment of the Republic of Indonesia No. 115 of 2003 About Guidelines for Determining Water Quality Status, 2003, pp.1-15, Jakarta.
Copyright (C) Int. J. of GEOMATE All rights reserved, including making copies unless permission is obtained from the copyright proprietors. 